Acta Univ. Sapientiae, Film and Media Studies, 19 (2021) 132-155

DOI: 10.2478/ausfm-2021-0009

\title{
The Tableau Vivant and Social Media Culture
}

\author{
Maria Männig \\ University of Koblenz-Landau (Landau, Germany) \\ E-mail: maennig@uni-landau.de
}

\begin{abstract}
The article aims to analyse the tableau vivant in social media culture by emphasizing its intermedial relation to technical visual media, particularly digital photography and film. By focusing on the living picture's specific mimetic qualities, the study traces back the tableau vivant's history in a media archaeological perspective primarily regarding photography. It explores the current revival of the tableau vivant within social media. The article examines living pictures and the aspect of self-staging, relevant to contemporary digital culture. The tableau vivant develops between two polarities: a primarily analytical approach that allows a profound exploration of a particular artwork and the performative aspects of self-staging.
\end{abstract}

Keywords: tableau vivant, social media, photography.

\section{A Medium Rarely Comes Alone: A Media-Theoretical Approach to the Tableau Vivant}

Enforced by using social media, sharing platforms, and pre-installed photo apps on smartphones, we can currently observe a return of the tableau vivant within digital popular culture. The tableau vivant experienced its very recent hype during the Covid-19 pandemic in 2020, when an Instagram account called Between Art and Quarantine came up with the idea to recreate paintings at home using a maximum of three household items. As large museums such as the Rijksmuseum in Amsterdam and the Getty in Los Angeles picked up the idea, it spread globally (Walldorf and Stephan 2020).

In order to analyse the tableau vivant as a phenomenon of social media culture in further detail, the argument will follow a media-theoretical reading of the tableau vivant. By focusing on its intermedial relations - to photography in particular - the article intends to trace back current social media practices in a media archaeological perspective (Huhtamo 2011) by analysing the (re)productive power of the tableau 
vivant as a performative act. A case study of the \#musepose social media initiative sheds light on the tableau vivant's historical roots as an educative tool, which it reactivates and modifies through digital culture. The production of tableaux vivants has been enabled by technical innovations such as the front camera, which is part of every smartphone. It links together the ancient fascination of mirroring the self and the reproductive pictorial power of photography.

Originally, tableaux vivants developed from a dialogue between painting and theatre during the eighteenth century by being staged as live performances in different contexts. From a theoretical point of view, the question is: can the tableau vivant be considered a medium? The media studies scholar Jens Ruchatz writes: "A medium only exists where there are also other media. In other words, something deserves the name 'medium' only if it is related to other phenomena that are also regarded as media, be it by observing them practically or discursively" $(2008,109)$. According to Ruchatz, only what is related to other media can be defined as a medium. The author develops this definition by confronting theatre and theatre photography, stating that "theatre is a medium when related to other media" (Ruchatz 2008, 115). Thus, its particular intermedial nature qualifies the tableau vivant a medium. I want to apply this basic concept to present the medium's transition to our current social media culture.

For instance, Birgit Jooss (2011) has shown that photography and tableau vivant practices overlap in early studio photography, which was considered the standard for theatre photography during the nineteenth century (Ruchatz 2008, 109-113). The ability to hold a pose for some minutes met the technical requirements for the long exposures required at the time. Since around 1870, the so-called Life Model slides were produced on demand, i.e. for magic lantern shows (Ruchatz 2003, 299). Professional actors were arranged into tableaux to tell a story in a series of photographic pictures. In reverse, photographs of tableau vivant performers were used to cut out the particular silhouettes of the postures to create specific lantern slides for projection that formed the backdrops within variety shows around 1900 (Wiegand 2016, 137).

While nineteenth-century discourses generally reflected upon photography's truthfulness concerning painting, this discussion continued in the opposition between the snapshot and staged photography - i.e. theatre and movie still photography - in the twentieth century (Jacobs 2010, 373-386). Yet, in the twentieth century, the actors had to pose for the photographer and re-enact a particular moment, which again reminds one of the tableau vivant practices (Ruchatz 2008, 110). By emphasizing the documentary value of photography, theatre studies 
regarded staged photography rather deficiently concerning the actual performance, which it failed to preserve.

Neither photography nor film has replaced the living picture; instead, they have incorporated it. Jooss explains the transfer of the tableau vivant into photography as a process of reproducing the reproduction (Jooss 2011, 15; Jooss 1999, 265). A high degree of mimesis is undoubtedly an inherent part of contemporary practices. Their analysis should include, however, also case studies of particular forms of appropriation, which would take into account the creative act of translating a specific historical model into a new media format.

\section{The Mirror and the Camera}

In Western culture, theories of mimesis have been crucial for drama, literature and the visual arts. Within the latter sphere, technical instruments for producing images have fascinated people throughout times and cultures. One of the simplest of these tools is the mirror (Macho 2002, 13-26). In Metamorphoses, specifically in the retelling of the myth of Narcissus, Ovid describes the allure of the water surface that has become an optical device. The dramatic character of the situation in which Narcissus has succumbed to his reflection becomes clear in a short passage in which the third-person narrator gives up his role and addresses his protagonist directly (Zwettler-Otte 2012, 36-50). "Fool, why try to catch a fleeting image, in vain? What you search for is nowhere: turning away, what you love is lost! What you perceive is the shadow of reflected form: nothing of you is in it. It comes and stays with you, and leaves with you, if you can leave!" (Ovid 2000, Book III, verses 432437.) Narcissus has fallen in love with his portrait but lacks the means to record or store it permanently. In Ovid's time, mirrors were made from polished metal. Later, executed in glass, they were as rare as they were precious. During the Middle Ages, they acquired magical properties in popular imagination. According to medieval beliefs, mirrors could catch the reflection and entrap people and animals, and even far more fabulous creatures, such as the unicorn. The mirror was also paradoxical in its symbolism: a symbol of chastity, it could also denote vanity. To warn against excessive vanity, it is one of Pride's attributes, the most serious of the deadly sins (for examples see Reidemeister 2006, 50).

In his seminal treatise De Pictura, Leon Battista Alberti (1404-1472) refers to Narcissus as the inventor of the art of painting, as he is the one who embraces the mirroring surface (Sinisgalli 2011, 46). Furthermore, Alberti tried to elucidate the mirror's image-generating quality in his theoretical work, along with offering 
practical suggestions for using the mirror during the painting process. It could serve - for example - to test a composition whose weaknesses would be revealed in the reversed image. Alberti assigned the mirror the function of "an excellent judge" (Sinisgalli 2011, 69) and Leonardo even called it a "teacher" (Belting, 1994, 76).

The reflection itself became a motif in Renaissance painting. In the context of the paragone, different art forms competed for the most seamless representation of reality. Painting was said to create the illusion of definitively fixing the fleeting simulacrum of the mirrored image. Parmigianino's famous Self-Portrait in a Convex Mirror (c. 1524) is a stunning example of such a "captured surface." Although it is a painting, the work is also a three-dimensional reproduction of a convex mirror. Therefore, it contains elements derived from both the art chamber piece but also sculpture. Parmigianino's piece is realistic in reproducing the curvy mirror image's distortions faithfully and surreally by transferring this alienated version of reality into painting. Aside from creating picture-in-picture effects, painted reflections like Parmigianino's began to continually expand the pictorial space and allow the artist to put bodies or objects into the picture in different views, as Hans Belting has shown in the case of early Netherlandish painting (1994, 74-79). Reflective surfaces display the painter's virtuosity and often serve as a three-dimensional representation of the pictured person and therefore allow painting to better compete with sculpture. W. J. T. Mitchell qualifies such "pictures on picturing" $(1994,61)$ metapictures and thus self-reflexive commentaries on the nature of images or the nature of their production.

The invention of photography would eventually change everything. Whereas pictures had been created artificially using the camera obscura for several centuries, they also had remained ephemeral, just like Narcissus's reflection in the water. In his famous book Magia Naturalis (1558), Giambattista della Porta describes the use of the camera obscura as a theatre of marvels that allows creating various simulacra (Pantin 2007, 100). The discovery of photosensitive substances finally allowed the camera obscura to record those images by technical means only. Joseph Nicéphore Niépce executed the first successful experiments in 1827, and the first marketable photographic process was published in 1839 by Louis-Jaques-Mandé Daguerre.

In the nineteenth-century discourse on photography, two influential groups faced each other. One fraction was enthusiastic about the truthfulness of the new medium and celebrated the notion that thanks to it, nature was now an artist able to record itself (Siegel 2017, 29-43). As early as 1840, one year after the publication of the Daguerreotype, the writer Edgar Allan Poe not only elaborated on the qualities of the photogenic drawings by comparing them to the mirror but also emphasized the 
seemingly infinite accuracy by magnifying the details using the new technique, which would exceed the functionality of the mirror. "Perhaps if we imagine the distinctness with which an object is reflected in a positively perfect mirror, we come as near the reality as by any other means. For, in truth, the Daguerreotyped plate is infinitely (we use the term advisedly) is infinitely more accurate in its representation than any painting by human hands." (Siegel 2017, 30. Emphasis in the original.) While celebrated by Poe and his fellow proponents of photography, this level of detail served as an argument against it by critics who argued that the photographic images would thus depict excessive, unnecessary information. Many visual artists of the nineteenth century remained sceptical of photography and claimed that the artist's eye would prevail over the lens (Alloa 2013, 107-126). Denying the art-worthiness of photography had become a topos that came to new life within the discussion of digital photography.

For Daguerre's contemporaries, the "process was often likened to a looking glass on which the mirror image of the sitter had been frozen" (Asser 2017, 81). From a phenomenological perspective, the silvery shiny surface of the Daguerreotype can be considered to have worked like a mirror (Siegel 2017, 30). It reflected the Daguerreotypists' face when they polished the plate during preparation and those looking at it after it had been processed. It is noticeable that the Daguerreotype can represent both a negative and a positive, depending on reflection. Looking at a Daguerreotype requires dealing with both the lighting and the reflection, which means the beholder has to move it when having it in hand (which was the most common practice for casketed Daguerreotypes) or to move around when it is hanging on the wall. In retrospect, the Daguerreotype' surface appears to be an animated one akin to today's smartphone displays.

Whereas they have been visible parts of apparatuses that helped to reorganize the perception like the Claude glass, the camera obscura or the camera lucida, mirrors became gradually hidden by the black box, i.e. in the single-lens reflex camera, patented in 1861, which used the mirror to display to the viewer the picture right-side-up. The introduction of the front-facing camera in 2003 led to the most significant paradigm shift that we have been able to observe in the history of (digital) photography, by merging the function of the camera with the display that allows to observe the actual result (Ruchatz 2018, 66-69) - and eventually has become Poe's "perfect mirror." Borrowing from Oliver Wendell Holmes's characterization of photography as a "mirror with a memory" (Ruchatz 2018, 67; Holmes 1864, 129) to think about selfies, Jens Ruchatz defines the selfie as a way of "picturing the taking of a picture" (2018, 68). Accordingly, one could thus classify selfie-taking as metaphotography. 
The front-facing camera only simulates the mirror image. In truth, it is an inverted camera image, which can be recorded directly as still or moving. In combination with the sharing functions provided by social networks, this multifunctional device has made today's selfie culture possible, which can be characterized by the fusion of the producer and the consumer. The display allows the photographer to control the shot, shows the pictured result immediately and offers the option to optimize it by repeating or editing it. In the following sections, I will further pursue this line of thinking by presenting how signals from the past mix with current selfie culture, resulting in a new amalgam of the old and new.

\section{The Tableau Vivant as an Educational Tool for Art History}

During the past two decades, scholars have not only explored the history of the tableau vivant but also elaborated intensively on the complex relations between this ephemeral art form and other media such as literature, painting, theatre (Brandl-Risi 2013; Jooss 1999), and (contemporary) art (Boucher and Contogouris 2019), music (Mungen 2006), photography (Jooss 2011), early cinema (Curtis, Gauthier, Gunning and Yumibe 2018; Schweinitz and Wiegand 2016), various forms of entertainment, from variety shows to festive culture (Wiegand 2016, Mungen 1998), and film (Pethő 2016, 233-256; Pethő 2014, 51-76; Jacobs 2011, 88-148; Barck 2008; Peucker 2007). The standard definition describes tableaux vivants as a kind of parlour game practised above all in noble circles during the nineteenth century. These games often showed off their creators' intelligence and erudition. They challenged their audience to recognize cited artworks and decode the hidden allusions of the performance that pointed to social relations within the group or personality traits of particular individuals.

As Birgit Jooss has shown, the tableau vivant practice correlates the emerging interest for art history. For instance, various forms of the Künstlerdrama presented the life and work of Raphael, Rubens, Caravaggio and other artists by implementing tableaux vivants (1999, 75-83). Starting in 1808, Henriette Hendel-Schütz performed a three-part programme that ranged from antique and Italian art to early German painting (Jooss 1999, 108-109). In contrast to Emma Hamilton's attitudes (Contogouris 2018, 78), Hendel-Schütz presented distinct stylistic differences of the eras and tried to outline their evolution. During the nineteenth century, these educational living pictures did not only serve taste-formation in general but informed the characterization of the stylistic traits of individual artists, different 
schools and even whole epochs. Therefore, as practised by performers such as Hendel-Schütz, the tableau vivant is a helpful witness to the emergence of both academic and popular art history.

According to Daniel Wiegand (2016), this particular practice continues into the twentieth century. The author has argued that the staging of canonical paintings and sculptures played a crucial role in establishing bourgeois entertainment culture around 1900 (Wiegand 2016, 124-179). The tableau vivant programmes of practitioners such as Henry de Vry included quotes from classical and classicist works of art and famous contemporary salon paintings. They, therefore, addressed the well-educated, art-loving middle class. Camillo Borghese - one of de Vry's competitors in the show business of the time - announced a "series of beautiful 'living pictures' from all parts of the world, based on my painterly compositions of the most magnificent motifs of my art study trips [...] as well as on the most outstanding works of important masters" (Wiegand 2016, 165). Through the implicit reference to the eighteenth-century tradition of the grand tour, Borghese advertised his living pictures to be based on what he had experienced on his travels. Appropriate to the historical context of the turn of the century, the authenticity of the programme promised by Borghese's tableaux vivants now extended to nothing less than a global level. Combined with electric lighting and projection techniques, the tableaux vivants were a significant part of the variety shows and anticipated forms of mass entertainment such as cinema.

Given that they were live events, like theatre, reports on tableaux vivants are mainly preserved in writing, whether of real or imagined tableaux. Bettina BrandlRisi argues that transformation into narration would be the only appropriate way to record the living picture's character $(2013,146)$. Although I do not fully agree with this interpretation, it helps map out the difficulties of visual representation. The tableau vivant substitutes the absent original by reproducing it for a short period and without necessarily becoming visually reproducible itself - at least before the advent of photography. In her research, Valentine Robert $(2018,2016)$ has presented various medial adaptions of late-nineteenth-century history paintings and their relation to early cinema. In the "age of the technological reproducibility" (Benjamin 2008 [1936], 22) the tableau vivant appears as a catalyst for ever-new adaptions covering all reproduction technologies from lantern slides to film celebrating productivity of the copy (Robert, 2016). When it comes to photographic reproduction, the performative interference with reality has to be considered another remarkable feature, according to Brigitte Peucker. "A tableau vivant [...] translates painting's flatness, its twodimensionality, into the three-dimensional. By this means it figures the introduction 
of the real into the image- - the living body into painting — thus attempting to collapse the distance between signifier and signified." (Peucker 2007, 31.)

Photography eventually allowed the fixing and distribution of the formerly transitory event beyond the moment of its execution. Through photography, the tableau vivant becomes a two-dimensional picture again - a picture containing traces of the real. According to Jooss, photography implied a media shift that doubled the tableau vivant's degree of reproducibility: "the re-enacted living picture - even already reproduced - became a reproducible 'new' original" (2011, $15 ; 1999,265)$. In other words, as a hybrid between painting, sculpture and theatre, the combination of tableaux vivants and photography created new intermedial relations. Photography freezes the period of the performance to eternity and reduces the sculptural arrangement to two-dimensionality. While manual reproductions make the living picture disappear, photography can preserve the difference between the living picture and the model.

\section{The Tableau Vivant as an Instrument for Self-Staging and Analysis}

Tableaux vivants allow the participants to stage themselves as particular protagonists referring to distinct epochs and artists; at the same time, the re-enactments require an accurate analysis of the original artwork. The French artist Edgar Degas, for example, arranged a tableau vivant after Jean-Auguste-Dominique Ingres's The Apotheosis of Homer, three decades after he had seen the iconic French painting at the Paris World Fair [Figs. 1-2]. Degas appears in the tableau as the protagonist Homer himself and gave instructions to the photographer who took the picture, Walter Barnes. Degas's self-staging includes not only the representation as the Greek poet Homer (as the most significant ancient storyteller) but also identifies the artist as pictor doctus. Furthermore, the photographed tableau vivant explicitly refers to Ingres, an idol of Neoclassicist French painting.

Sonja Maria Krämer has recently called into question the picture's widely recognized reading as an ironic statement (Krämer 2014, 127-128; Daniel 1998, 19; Daniel 2005, 399). Due to their particular character, containing costumes, coulisses and various kinds of accessories, photographed tableaux vivants are often misinterpreted by art historians as both failing to create a proper illusion in comparison to painting and meeting the indexical quality of photography only insufficiently (Rödl 2019, 142). This actual difference marks the specific hybridity between the image and the real. 
The sources prove the analytical approach required for the re-enactments of works of art. In one of the many letters that Degas addressed to his close friend Ludovic Halévy (Guérin 1945, 112) - a French playwright with whom Degas seems to have planned other tableaux vivants (Guérin 1945, 107, 111), Degas similarly judges the photographed tableau vivant as he would have judged a painting and thus considers himself the author (Krämer 2014, 128). He argues, for instance, that architectural details such as the structure of the brick wall are disturbing and that a white or bright background would have helped to clarify the composition. Krämer concludes from this that any parodic effect if there is one, was unintentional. This photograph also marks a starting point for Degas's later photographic work, which would be dominated by the self-portrait, thus enabling him to act as both the photographer and the model (Daniel 1998, 89).

As a photographer, Degas would later prefer working at night by artificial lighting to hide unnecessary details. Therefore, it can be considered a synthesis of the already mentioned nineteenth-century discourse that appreciated the medium's accuracy on the one hand and criticized its abundance of visual information on the other. The Apotheosis helps to demonstrate the challenges of photographic tableau vivant practices in the nineteenth century, which did not allow the author - in this case: Degas - to keep full control of the process, as he was neither able to pose and to photograph at the same time nor to evaluate and adjust the result immediately.

Virginia Oldoini Verasis, better known as Comtesse di Castiglione can be considered an early example of a particular female artistic approach to both fields, photography and tableaux vivants (Solomon-Godeau 1986, 87). Robert de Montesquiou, one of her contemporaries and later biographer, characterized Verasis's life as "nothing but a lengthy tableau vivant, a perpetual tableau vivant" (Solomon-Godeau 1986, 76). In collaboration with the court photographer PierreLouis Pierson, Verasis realized the impressive number of more than 474 photographs (Stiegler 2019, 232-234). Various examples from this bundle reflect the medium of photography itself. One of those shows the countess sitting as a half-length figure slightly diagonally. She is masking her face partly by holding an oval passe-partout. In a second photograph, Verasis poses as a Weeper pressing a handkerchief into her face. ${ }^{1}$ The picture frame, which is right in the centre of the composition qualifies the posing as a living picture. To comment ironically on that rectangular boundary, the countess has put her hand right on the lower part of the frame (Stiegler 2019, 232). Parts of the countess's body are just as visible as the whole apparatus, consisting of a table serving as a pedestal for both the posing countess and the picture frame. The

1 The picture can be found in Solomon-Godeau 1986, 74. 
latter is set into place by a nineteenth-century neckrest belonging to the essential equipment of early studio photography and, therefore, helped keep models steady during the long exposure times. The ability to hold a pose for some minutes met the technical requirements for the long exposures required by early photographic processes. Hence, a close relationship between photography and the tableau vivant on both a culture-historical and structural level should be taken into consideration.

The constant reduction of exposure times during the nineteenth century led to a growing appreciation of the snapshot and simultaneously to a devaluation of studio photography. Furthermore, emphasizing indexicality became the dominant discourse in photo theory during the twentieth century, for instance, in Barthes's writings, who classified photography as evidence for the real. Retrospectively, Barthes's formula of the "that-has-been" $(1981,77)$ was - and still is - applied to early photography that existed under different technical and discursive conditions. In this reading, the snapshot appears as a genuine photograph in contrast to staged photography. Lewis Carroll's poem Hiawatha's Photographing can be read as an observation of that aesthetic shift from staged photography to the snapshot. It contains traces of both the tableau vivant practice and early studio photography. Written in 1887 Carroll, also a passionate photographer elucidates the technical challenges of portraying people. According to the text, the older family members mainly try to take painterly poses by imitating historical figures or referring to aesthetic theory. The father impersonates Napoleon, whereas the son performs Ruskin's "curves of beauty" and the daughter poses as a "passive beauty" (Wilsher 1979). Each verse comprises one shooting that eventually fails. Against all probabilities and expectations, the photographer only succeeds in capturing the youngest son. The latter is entirely unwilling to become photographed and therefore behaves most naturally in front of the camera. While the older protagonists point backwards in time by adhering to traditional aesthetic formulas inherent to other media like painting and sculpture, the child and the new technique merge successfully by pointing towards the future of photography. In his literary snapshot, Carroll allows photographic accuracy to conflate with the idea of the right moment.

\section{Stillness and Motion in Cinema}

Against the backdrop of cinema, the existence of the (still) image has remained challenging. In both Pier Paolo Pasolini's Ricotta (1960) and Jean-Luc Godard's Passion (1982), the mise-en-scène of tableaux vivants is crucial and serves as a metaphor for filmmaking (Barck 2008, 192-271; Jacobs 2011, 88-120; Paech 1989). 
On a structural level, each of the two examples represents a film-in-film concept. In both cases, the main protagonists are directors who fail to stage famous paintings at first sight. However, the two movies differ significantly in their cinematic implementation. Whereas Pasolini uses luscious colours and music to distinguish the tableau vivant scenes from the storyline in black-and-white, the tableaux vivants and the "story" consequently overlap in Godard's case as it regards the formal level and that of the plot. Pasolini's camera remains to scan the surface of the living picture. In contrast, Godard's camera work differs from his predecessor's in that it penetrates the tableaux by creating new perspectives and, as a consequence, strikingly new narratives (Paech 1989, 17).

Throughout the sequence of the different tableaux, Godard pushes the limits of cinematic means. Whereas the first tableau of Rembrandt's Night Watch remains identifiable, already in the following Goya scene, a dolly shot explores the timespatial arrangement of The Third of May 1808. Hence, it creates new tableaux vivants by moving through several pictures, by focusing on details, by changing the perspectives to examine the three-dimensional structure. In contrast to photography, the motion picture can capture what I would like to call the paradox of stillness. The stillness is paradoxical in that the classical tableau vivant implies "bringing images to life" by actors "playing" lifeless figures in a painting. Film is not only able to document this paradox but to exploit the opposition of stillness and motion for artistic purposes (Wiegand 2016, 71-72, 269-292). Caroline Chik defined the existing dichotomy between stillness and motion as "l'image fixe-animée" (2011, 249-263) by pointing to the close link between photography and film, considering the former a still and the latter a moving version of the technically generated image.

By aiming at "filming like a painter paints" (Paech 1989, 10) and thus raising the issue of the paragone again, Godard's gaze delves into the paintings. From inside, he visually investigates how gestures work (Paech 1989, 14), a method which refers back to Aby Warburg and beyond that to sensualist art theory. Through the posing of the tableaux vivants, as Joachim Paech has shown, the filmmaker is allowed to blend both painting and filmmaking. Passion thus represents a "metafilm" (1989, 64 ) that - equivalent to the concept of metapicture (or, metaphotography) - reflects upon the process of its own making.

Gustav Deutsch took the cinematic tableau vivant to another extreme by composing a filmic narrative out of a chronically arranged selection of Hopperpaintings in Shirley. Visions of Reality (2013). The Hopper paintings in Deutsch's production are revived into living pictures by the actors' performances. Monologues and dialogues accentuate the static scenes with the purpose to expand the painterly 
Kairos - or the "pregnant moment" lighting and the set design, in which painting plays a central role again, recreate the synthetic character of colouring and atmosphere typical of Hopper's artistic style.

Their framing defines both film and painting, even tableaux vivants were repeatedly staged in frames simulating an easel painting (Jooss 1999, 152-164). In Europe, the geometrical shape became the standard for the painted picture during the Renaissance. According to the Gestalt theorist and film scholar Rudolf Arnheim, the strict limitation of the film image makes the difference from the human gaze (2002, 31-32). According to his argument, this particular finiteness serves as the condition under which film can become an art. The limited rectangular surface has to be designed by cinematic means. The spatial limitation has also been crucial for Jaques Lacan, who noticed that paintings would serve to tame the gaze due to their finiteness only (Lacan 1972, 116). Whereas the boundaries of the film image, in general, are comparable to those of a painting or photograph, the mobile camera allows entering and exploring other dimensions such as depth or space and, therefore, to dissolve the borders of the original painting by creating new images ever. ${ }^{3}$

Twelve chapters structure Shirley's storyline. Based on the piece Western Motel, chapter eight re-enacts the making of the painting as a photo shooting. Steven, the male photographer, remains invisible, his presence is marked by his voice only. Offcamera, he gives the typical short instructions, such as "Turn your head" or "Look at me." Several possible versions are acted out by merging fundamental operations of painting, photographing, and filmmaking. Shirley, the female character takes up different poses until the sentence "Turn your body towards me and put your hand on the bed" marks the closest approximation to the Hopper painting [Fig. 3]. The photographer's instructions are thwarted by an inner monologue of the female protagonist to subvert the gendered stereotype of the (active) artist and the (passive) muse. In her monologue, Shirley addresses the process of mirroring metaphorically: "He became a stranger to me at that moment as I might have been for him as well a woman that wanted to behave and to look like the woman he imagined for his photograph.” The statement describes not only the discomfort and alienation caused by the shooting but also the interference of individual thoughts mainly regarding the imagined or the intended image.

2 Gotthold Ephraim Lessing worked out this idea in his famous Laocoön essay in 1766 by addressing the relation of literature and visual arts (Jooss 1999, 49).

3 The new technical media challenged the question of what an image is. The aesthetic of the image's boundaries was also put into question in Verasis's photos mentioned earlier. The carved golden picture frame and the cardboard frame mark the border between the picture as something to contemplate about in order to differentiate it from the rest of the world. 


\section{Social Media and the Return of the Tableau Vivant: \#Musepose}

Unlike in Degas's times, when the practice of the tableau vivant most often had to rely on manual reproductions and memory and visualized something absent, the omnipresence of the smartphone led to both a stronger presence of photography and an acceptance within the institutions; therefore, staging tableaux vivants onsite in art collections and museums, right in front of the originals has become a common practice. Unsatisfactory recreations can be monitored in real-time via the mirroring screen surface and corrected on the spot. Smartphone users who create living pictures in museums thus have to compete more directly with the model.

Museum pedagogy has seized on the possibilities afforded by smartphone cameras to turn the outdated medium of the tableau vivant into contemporary "edutainment." It has developed specific social media campaigns out of it, like \#musepose, launched by the Getty Museum in January 2015 (Chan, Westover and Williams 2015), in a kind of reactivation of the tableau vivant as art-historical education seen in the nineteenth century, as mentioned above. ${ }^{4}$ Apart from this particular project, similar re-enactments of artworks appear regularly within social media. Within the original project, \#musepose, visitors were invited to create individual works in the style of tableaux vivants and share their results immediately and globally on Instagram with the particular hashtag. To run a successful social media campaign, the level of effort has to be relatively low so that spontaneity can be privileged: participants do without the costumes and stage settings that were essential components of the tableaux vivants of the past. In general, each posted photograph appears as an entity within the grid structure typical for Instagram.

A closer examination of the posts reveals two common characteristics. Firstly, participants of the action prefer figurative works. Secondly, they chose pieces in which eccentric facial expressions or gestures - with references to daily life - play a role. Due to these features, works from the eighteenth century profit from this new economy of digital attention.

The visual arts from the eighteenth century were influenced by the modern sensualism expounded by Diderot and others: a discourse exemplarily manifested - for instance - in Franz Xaver Messerschmidt's physiognomic studies. Despite being expressively exaggerated, his Character Heads (1777/1783) - a series of busts showing different kinds of grimaces - seem to encourage imitation by the visitors especially [Fig. 4]. At the Austrian court for which Messerschmidt worked, facial

4 Labels next to the pieces encouraged the visitors to strike a pose, take a selfie and to share it. 
expressions had to be actively controlled, and in response, the artist developed an interest in depicting less controlled outward displays of inner discord. This interest made him ripe for rediscovery in the twentieth century by scholars such as Ernst Kris. Unfortunately, he pathologized the character heads by assuming that their author had a personality disorder (Kris 1933). More soberly, they can be interpreted as a transfer of physiognomic studies from two-dimensionality into the field of sculpture. Thus, they also stand in the tradition of paragone, the competition for the superiority of the art forms.

The French artist Charles Le Brun (1619-1690) was central to Messerschmidt's work. As early as 1668, Le Brun had systematized the primary emotional expressions intending to create a decodable system that could serve as a guide for artists. His Méthode pour apprendre à dessiner les passions appeared posthumously in 1698 (Le Brun 1702). The treatise was distributed widely throughout Europe and had a strong influence on the eighteenth century's sensualistic art theories and artistic practice. Subsequently, the ability to adequately depict an inner movement became an absolute requirement for painting. Messerschmidt eventually transferred Le Brun's images of facial expression into sculpture. As the precursors of today's standard emojis, such images reappeared in instructional books and photographic albums made for artists' education. Today, museum visitors seem to associate Messerschmidt's bust [Fig. 4] entitled the Vexed Man with emojis such as the confounded face, as comments on one Instagram post show. Recognizability, the life-size and the sculpture's haptic quality likely all facilitate the visitors' ability to imitate.

The age, ethnicity and gender of the museposers vary, as does the number of participants in any given imitation. The composition, the chosen perspective, the degree of variation and interpretation, and the performative and photographic execution quality also differ. It is noticeable that the photos posted under \#musepose show individuals primarily. The fact that group scenes form a minority of the posted photos and that the reproduced originals are present in the picture prompts the question: to what extent does the definition of the tableau vivant remain applicable for this contemporary phenomenon? Although it appears to be modified, the tableau vivant practice remains discernible. Unlike the classicist living pictures that represented something absent, one feature of \#musepose and beyond that selfie culture, in general, is that the original work of art becomes a part of the picture in most cases and is thus also an actor. Although most of the examples are executed in a rather traditional way, collaboratively by a photographer and a model, my argument is that this kind of shot is nevertheless immanent to - and explainable by - selfie culture. The latter enables the participants to reproduce the original 
through embodiment and document this act of representation before the work that they are embodying. Moreover, it builds on previous experience gained through producing selfies by re-enacting conventionalized poses and facial expressions such as the duck face. Through photography, the museposers enter into a complex dialogue with the original, which combines two opposing processes: one directed introspectively by documenting the individual aesthetic experience and the other extravertive, by addressing the audience by sharing the result on a platform. As already shown, the tableau vivant's history fluctuates between the aspects of selfstaging and analytical approach. Both conditions represent fleeting moments that were unrecordable in the past. Moreover, by transforming a rather casual gesture of photo documentation into a metaphotograph, the external performance of the museposers may adhere to the concept mentioned above of selfie reflexivity. In one remarkable example, a museposer imitates Messerschmidt's Vexed Man, albeit with open eyes [Fig. 5]. The virtual button of the front camera requires him to look at the display while taking the shot.

Each of these mimetic acts potentially becomes a model for new strategies of imitation. Angela Krewani argues that digital communication is based on digital feedback processes and digital loops. Thus, "the self and the represented self turn into a recursive mediated structure" (Krewani 2018, 97). I would like to elaborate on Krewani's information-theory based explanation regarding the feedback loop's perception primarily as a visual phenomenon that continuously activates the mimetic drive, i.e. the impulse to imitate. The images posted with the hashtag \#musepose do not only address the general public accessing the images digitally but also serve as a model for individual adaptions. Hence, particular motifs and compositions are constantly repeated. The social interaction significant for the tableau vivant practice of the eighteenth and nineteenth centuries has shifted to the virtual space. On social media platforms, the individuals generate their actual network that becomes evident in the number of followers, likes and comments.

Art institutions feared that dwindling visitor numbers would result from digital platforms and high-resolution scans of their collections, but the exact opposite has manifested in recent years. The images imitating images and selfies on such platforms as Instagram have led to rethinking museum policy in recent years. More expressive forms of appropriation are now replacing contemplative forms of art enjoyment. The impulse to document the individual experience visually that has accompanied the growth of social networking, to provide digital proof of one's experience seems to be compulsive and is continuously branching out into different genres, subgenres and trends. Moreover, selfie culture allows visitors to appropriate 
the artworks, at least in a figurative sense. The specific forms of appropriation and empowerment discernible in trends such as \#musepose invite us to examine not only the extent to which contemporary tableau vivant practice is indebted to the historical but vice versa, how current phenomena could inform on the past. With a view on these present practices, we can observe that the tableau vivant's never-ending story results in constant need for actualized forms of appropriation according to changing technical and social conditions.

What is more, if we consider selfie photography as a self-reflexive practice, this brings to the fore the self-consciousness immanent to the tableau vivant. Apart from popular culture, the tableau vivant remains a relevant phenomenon in the arts. It has experienced the first wave of revival during postmodernism (Halimi 2019) and is facing the second one in contemporary digital culture. The obvious co-existence of still and moving images that can be traced back in media history, according to Chik (2011) characterizes the latter. During the state of exception caused by the pandemic, staging tableaux vivants even became a possibility for appropriating the absent original within the digital sphere in its neoclassical sense again.

\section{References}

Alloa, Emanuel. 2013. Eilender Stillstand - elender Stillstand. Merleau-Ponty und die Ambivalenzen der Chronofotografie [Hurrying Standstill - Miserable Standstill. Merleau-Ponty and the Ambivalences of Chronophotography]. In Erscheinung und Ereignis. Zur Zeitlichkeit des Bildes [Appearance and Event. The Temporality of the Picture], ed. Emanuel Alloa, 107-126. Munich: Fink. Arnheim, Rudolf. 2002 [1932]. Film als Kunst [Film as Art]. Munich: Suhrkamp. Asser, Saskia. 2017. Early Days. In New Realities. Photography in the 19th century, eds. Mattie Boom and Hans Roseboom, 80-84. Amsterdam: Rijksmuseum.

Barck, Joanna. 2008. Hin zum Film - Zurück zu den Bildern. Tableaux Vivants: "Lebende Bilder" in Filmen von Antamoro, Korda, Visconti und Pasolini [Towards the Film - Back to the Pictures. Tableaux Vivants: "Living Images" in Films by Antamoro, Korda, Visconti and Pasolini]. Bielefeld: transcript.

Barthes, Roland. 1981. Camera Lucida. Reflections on Photography. New York: Hill \& Wang.

Benjamin, Walter. 2008 [1936]. The Work of Art in the Age of Its Technological Reproducibility (Second Version). In Walter Benjamin. The Work of Art in the Age of Its Technological Reproducibility, and Other Writings on Media, eds. 
Michael W. Jennings, Brigid Doherty and Thomas Y. Levin, 19-55. Cambridge, London: The Belknap Press of Harvard University Press.

Belting, Hans. 1994. Die Erfindung des Gemäldes [The Invention of the Painting]. In Die Erfindung des Gemäldes. Das erste Jahrhundert der niederländischen Malerei [The Invention of the Painting. The First Century of Dutch Painting], eds. Hans Belting and Christiane Kruse, 33-93. Munich: Hirmer.

Brandl-Risi, Bettina. 2013. BilderSzenen. Tableaux Vivants zwischen bildender Kunst und Literatur im 19. Jahrhundert [Picture Scenes. Tableaux Vivants between Visual Arts and Literature in the 19th Century]. Freiburg i. Brsg., Berlin, Vienna: Rombach.

Boucher, Mélanie and Ersy Contogouris, eds. 2019. Stay Still: Past, Present, and Practice of the Tableau Vivant / Stay Still: histoire, actualité et pratique du tableau vivant [special issue]. RACAR vol. 44, no. 2.

Chan, Audrey, Andrew Westover and Kelly Williams. 2015. Strike a \#MusePose! the iris. Behind the Scenes at the Getty. http://blogs.getty.edu/iris/strike-a-musepose/. Last accessed 05. 08. 2020.

Chik, Caroline. 2011. L'image paradoxale [The Paradoxical Image]. Paris: Villeneuve d'Ascq: Presses universitaires du Septentrion.

Contogouris, Ersy. 2018. Emma Hamilton and Late Eighteenth-Century European Art. Agency, Performance, and Representation. New York, London: Routledge.

Curtis, Scott, Philippe Gauthier, Tom Gunning and Joshua Yumibe, eds. 2018. The Image in Early Cinema. Form and Material. Indiana: Indiana University Press.

Daniel, Malcolm. 1998. “The Atmosphere of Lamps or Moonlight.” In Edgar Degas, Photographer, ed. Malcolm Daniel, 17-52. New York: The Metropolitan Museum of Art.

Daniel, Malcolm. 2005. Degas, Edgar. In Encyclopedia of Nineteenth-Century Photography vol. 1, ed. John Hannavy, 399-400. New York: Routledge.

Fiorentini, Erna. 2006. Camera Obscura vs. Camera Lucida. Distinguishing Early Nineteenth Century Modes of Seeing. Berlin: Max Planck Institute for the History of Science.

Groen, Karin. 2007. Painting Technique in the Seventeenth Century in Holland and the Possible Use of the Camera Obscura by Vermeer. In Inside the Camera Obscura - Optics and Art under the Spell of the Projected Image, ed. Wolfgang Lefèvre, 195-210. Berlin: Max Planck Institute for the History of Science.

Guérin, Marcel, ed. 1945. Lettres de Degas [Letters from Degas]. Paris: Éditions Bernard Grasset. 
Halimi, Carole. 2019. Tableau vivant et postmodernité: quelles affinités? [Tableau Vivant and Postmodernity: what Affinities?] In Stay Still: Past, Present, and Practice of the Tableau Vivant / Stay Still: histoire, actualité et pratique du tableau vivant [special issue], eds. Mélanie Boucher and Ersy Contogouris. RACAR vol. 44, no. 2: 19-30.

Holmes, Oliver Wendell. 1864. The Stereoscope and the Stereograph. In Soundings from the Atlantic, ed. Oliver Wendell Holmes, 124-165. Boston: Ticknor and Fields.

Huhtamo, Erkki. 2011. Dismantling the Fairy Engine: Media Archaeology as Topos Study. In Media Archaeology: Approaches, Applications, and Implications, eds. Erkki Huhtamo and Jussi Parikka, 27-47. Berkeley: University of California Press. Jacobs, Steven. 2010. The History and Aesthetics of the Classical Film Still. History of Photography vol. 34, no. 4: 373-386.

Jacobs, Steven. 2011. Framing Pictures. Film and the Visual Arts. Edinburgh: Edinburgh University Press.

Jooss, Birgit. 1999. Lebende Bilder. Körperliche Nachahmung von Kunstwerken in der Goethezeit [Living Pictures. Physical Imitation of Works of Art in Goethe's Time]. Berlin: Reimer.

Jooss, Birgit. 2011. Tableaux und Attitüden als Inspirationsquelle inszenierter Fotografie im 19. Jahrhundert [Tableaux and Attitudes as Sources of Inspiration for Staged Photography in the 19th Century]. In Rollenspiele - Rollenbilder [Role Plays - Role Models], eds. Toni Stoos and Esther Ruelfs, 14-47. Munich: Hirmer. Krämer, Sonja Maria. 2014. Kat. 34. Die Apotheose von Degas (Tableau vivant nach Jean-Auguste-Dominique Ingres) [The Apotheosis of Degas (Tableau Vivant after Jean-Auguste-Dominique Ingres)]. In Degas. Klassik und Experiment [Degas. Classic and Experiment], ed. Alexander Eiling exh. cat. Staatliche Kunsthalle Karlsruhe, 127-128. Munich: Hirmer.

Krewani, Angela. 2018. The Selfie as Feedback: Video, Narcissism, and the ClosedCircuit Video Installation. In Exploring the Selfie. Historical, Theoretical, and Analytical Approaches to Digital Self-Photography, eds. Julia Eckel, Jens Ruchatz and Sabine Wirth, 95-110. Cham: Palgrave Macmillan.

Kris, Ernst. 1933. Ein geisteskranker Bildhauer: Die Charakterköpfe des Franz Xaver Messerschmidt [A Mentally Ill Sculptor: the Character Heads of Franz Xaver Messerschmidt]. Imago vol. 19: 384-411.

Lacan, Jean. 1972. Was ist ein Bild/Tableau [What is a Picture/Tableau]. In Das Seminar von Jaques Lacan, Buch XI, Die vier Grundbegriffe der Psychoanalyse 
[Jacques Lacan's Seminar, Book XI, The Four Basic Concepts of Psychoanalysis], ed. Jaques-Alain Miller, 112-126. Weinheim: Quadriga.

Le Brun, Charles. 1702. Méthode pour apprendre à dessiner les passions proposé dans conférence sur l'expression générale et particulière [A Method to Learn to

Design the Passions, Proposed in a Conference on their General and Particular Expression]. Hildesheim, Zürich, New York: Olms. [Repr. 1982]

Lessing, Gotthold Ephraim. 1984 [1766]. Laocoon: An Essay on the Limits of Painting and Poetry. Baltimore MD and London: Johns Hopkins University Press.

Macho, Thomas. 2002. Narziß und der Spiegel. Selbstrepräsentation in der Geschichte der Optik [Narcissus and the Mirror. Self-Representation in the History of Optics]. In Narcissus. Ein Mythos von der Antike bis zum Cyberspace [Narcissus. A Myth from Ancient Times to Cyberspace], ed. Almut-Barbara Renger, 13-25. Stuttgart, Weimar: Metzler.

Mitchell, William John Thomas. 1994. Picture Theory. Chicago: University of Chicago Press.

Mungen, Anno. 1998. Das Bild im Bild. Lebende Bilder als Medium der Kunst und Unterhaltung [The Picture in the Picture. Living Pictures as a Medium of Art and Entertainment]. In Feste zur Ehre und zum Vergnügen. Künstlerfeste des 19. und frühen 20. Jahrhunderts [Celebrations of Honor and Pleasure. Artist Festivals of the 19th and Early 20th Centuries], ed. Ingrid Bodsch, 43-59. Bonn: Stadtmuseum Bonn.

Mungen, Anno. 2006. BilderMusik. Panoramen, Tableaux vivants und Lichtbilder als multimediale Darstellungsformen in Theater- und Musikaufführungen vom 19. bis zum frühen 20. Jahrhundert [Picture Music. Panoramas, Tableaux Vivants and Photographs as Multimedia Forms of Representation in Theater and Music Performances from the 19th to the Early 20th Century]. Remscheid: Gardez! Verlag.

Ovid. 2000. Metamorphoses. https://ovid.lib.virginia.edu/trans/Ovhome.htm. Last accessed 26. 01. 2021.

Paech, Joachim. 1989. Passion oder die Einbildungen des Jean-Luc Godard [Passion or the Imaginations of Jean-Luc Godard]. Frankfurt am Main: Deutsches Filmmuseum.

Pantin, Isabelle. 2007. "Res Aspectabilis Cujus Forma Luminis Beneficio per Foramen Transparet" - Simulachrum, Species, Forma, Imago: What was Transported by Light through the Pinhole? In Inside the Camera Obscura - Optics and Art under the Spell of the Projected Image, ed. Wolfgang Lefèvre, 95-104. Berlin: Max Planck Institute for the History of Science. 
Pethő, Ágnes. 2014. The Tableau Vivant as a "Figure of Return" in Contemporary East European Cinema. Acta Universitatis Sapientiae, Film and Media Studies vol. 9: 51-76.

Pethő, Ágnes. 2016. Figurations of the Photofilmic: Stillness versus MotionStillness in Motion. In The Photofilmic. Entangled Images in Contemporary Art and Visual Culture, eds. Brianne Cohen and Alexander Streitberger, 233-256. Leuven: Leuven University Press.

Peucker, Brigitte. 2007. The Material Image. Art and the Real in Film. Stanford: Stanford University Press.

Reidemeister, Johann. 2006. Superbia und Narziß. Personifikation und Allegorie in Miniaturen mittelalterlicher Handschriften [Superbia and Narcissus. Personification and Allegory in Miniatures of Medieval Manuscripts]. Turnhout: Brepols.

Robert, Valentine. 2016. "Die letzten Patronen” der ersten Historienfilme. Zur malerischen Qualität des frühen Filmbildes ["The Last Cartridges” from the First Period Films. On the Painterly Quality of the Early Film Image]. In Film Bild Kunst. Visuelle Ästhetik des vorklassischen Stummfilms [Film Picture Art. Visual Aesthetics of the Pre-Classical Silent Film], eds. Jörg Schweinitz and Daniel Wiegand, 117-150, Marburg: Schüren.

Robert, Valentine. 2018. La part picturale du tableau-style [The Pictorial in the Tableau Style]. In The Image in Early Cinema. Form and Material, eds. Scott Curtis, Philippe Gauthier, Tom Gunning and Yoshua Yumibe, 15-25. Indiana: Indiana University Press.

Rödl, Ines. 2019. “Zwitterwesen zwischen Mahlerey und Theater.” Vergangenheit in Fotografie und Malerei im 19. Jahrhundert ["Hybrid between Painting and Theater." Past in Photography and Painting in the 19th Century]. In Licht und Leinwand. Fotografie und Malerei im 19. Jahrhundert [Light and Canvas. Photography and Painting in the 19th Century], eds. Leonie Beiersdorf, G. Ullrich Großmann and Pia Müller-Tamm exh. cat. Staatliche Kunsthalle Karlsruhe, 133152. Munich: Deutscher Kunstverlag.

Ruchatz, Jens. 2003. Licht und Wahrheit. Eine Mediumgeschichte der fotografischen Projektion [Light and Truth. A Medium History of Photographic Projection]. Munich: Fink.

Ruchatz, Jens. 2008. Zeit des Theaters/Zeit der Fotografie. Intermediale Verschränkungen [Time of Theater/Time of Photography. Intermedial Entanglements]. In Theater und Medien / Theatre and the Media. Grundlagen - Analysen - Perspektiven. Eine Bestandsaufnahme [Theatre and Media/ 
Theatre and the Media. Basics - Studies - Perspectives. An Inventory], eds. Henri Schoenmakers, Stefan Bläske, Kay Kirchmann and Jens Ruchatz, 109-117. Bielefeld: transcript.

Ruchatz, Jens. 2018. Selfie Reflexivity: Pictures of People Taking Photographs. In Exploring the Selfie. Historical, Theoretical, and Analytical Approaches to Digital Self-Photography, eds. Julia Eckel, Jens Ruchatz and Sabine Wirth, 49-82. Cham: Palgrave MacMillan.

Schweinitz, Jörg and Daniel Wiegand, eds. 2016. Film Bild Kunst. Visuelle Ästhetik des vorklassischen Stummfilms [Film Picture Art. Visual Aesthetics of the PreClassical Silent Film] Marburg: Schüren.

Siegel, Steffen. 2017. No Room For Doubt? Daguerre and His First Critics. In Photography and Doubt, eds. Sabine T. Kriebel and Andrés Mario Zervigón, 2943. New York: Routledge.

Sinisgalli, Rocco, ed. 2011. Leon Battista Alberti. On Painting. Cambridge: Cambridge University Press.

Solomon-Godeau, Abigail. 1986. The Legs of the Countess. October, no. 39 (Winter): 65-108.

Stiegler, Bernd and Felix Thürlemann. 2019. Konstruierte Wirklichkeiten. Die fotografische Montage 1839-1900 [Constructed Realities. Photographic Montage 1839-1900]. Berlin: Schwabe.

Waldorf, Sarah and Annelisa Stephan. 2020. Getty Artworks Recreated with Household Items by Creative Geniuses the World Over. the iris. Behind the Scenes at the Getty. http://blogs.getty.edu/iris/getty-artworks-recreated-with-householditems-by-creative-geniuses-the-world-over/. Last accessed 05. 08. 2020.

Wiegand, Daniel. 2016. Gebannte Bewegung. Tableaux Vivants und früher Film in der Kultur der Moderne [Banned Movement. Tableaux Vivants and Early Film in Modern Culture]. Marburg: Schüren.

Wilsher, Ann. 1979. 'Hiawatha's Photographing:' Lewis Carroll and A. B. Frost. History of Photography vol. 3, no. 4: 304.

Zwettler-Otte, Sylvia. 2012. Narzissmus im Spiegel antiker Mythologie [Narcissism as Reflected in Ancient Mythology]. In Der Spiegel des Narziss. Vom mythologischen Halbgott zum Massenphänomen [Narcissus's Mirror. From Mythological Demigod to Mass Phenomenon], ed. Beate Ermacora and Maren Welsh, exh. cat. Galerie im Taxispalais, Innsbruck, 36-51. Cologne: Snoeck. 


\section{List of Figures}

Figure 1. Walter Barnes / Edgar Degas Apotheosis de Degas (After Ingres's L'apotheose d'Homere), 1885, Albumen silver print, $8.3 \times 9.5 \mathrm{~cm}$. The J. Paul Getty Museum, Los Angeles. Digital image courtesy of the Getty’s Open Content Program.

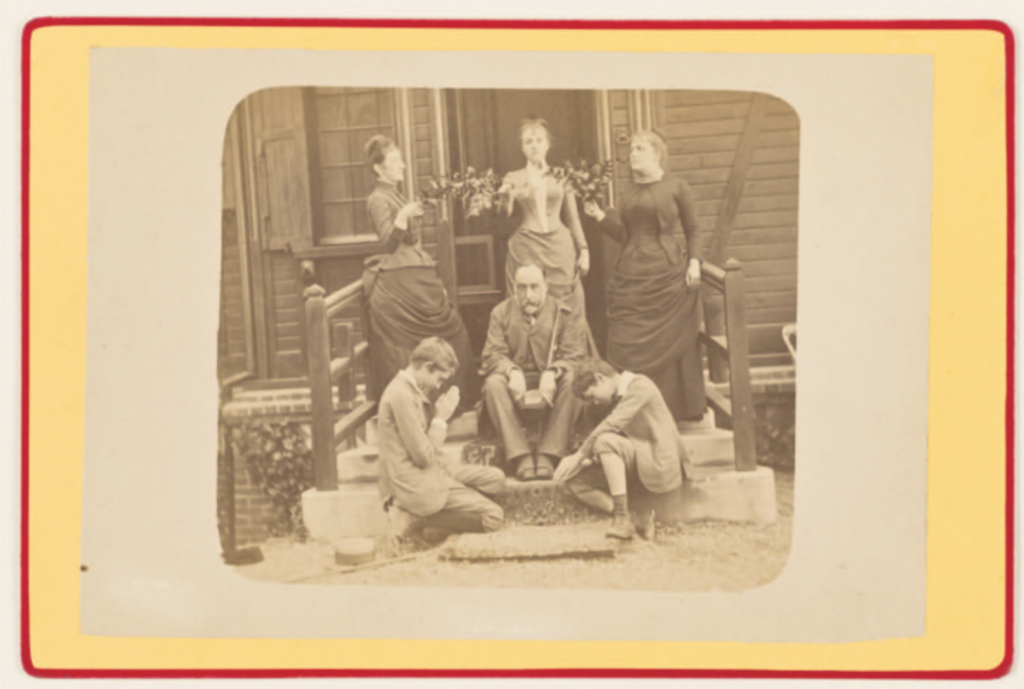

Figure 2. Jean-Auguste-Dominique Ingres, Apotheosis of Homer, 1827, 386 x 515 cm.

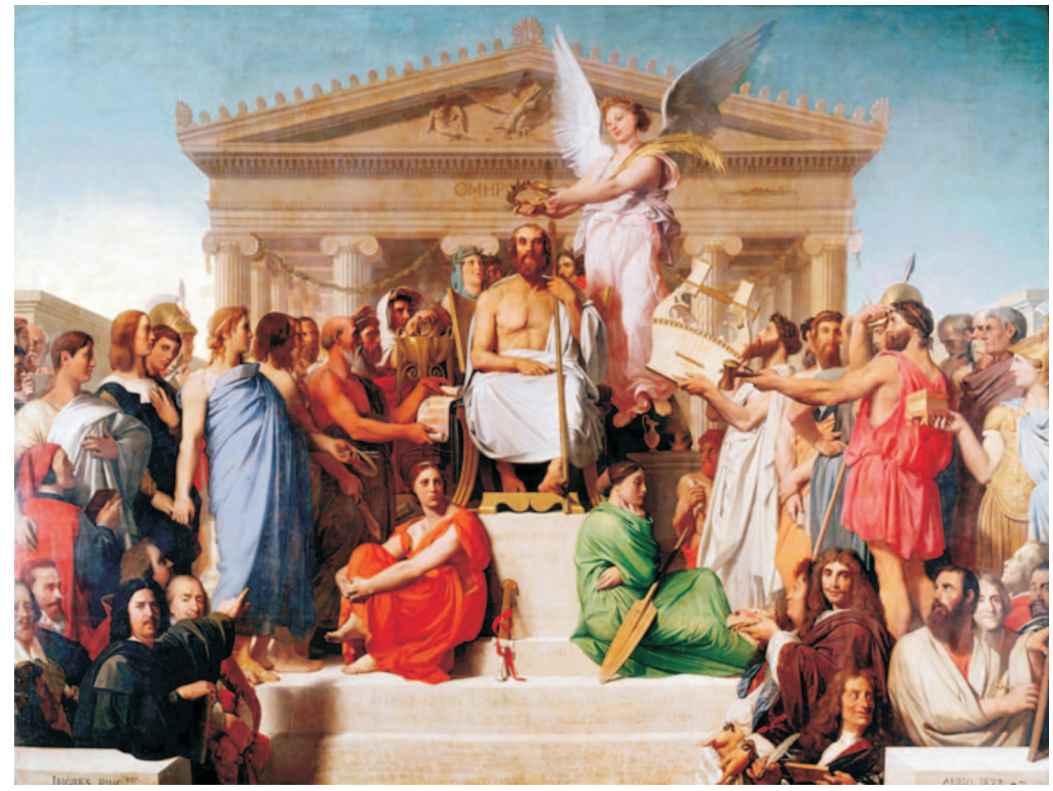


Figure 3. Shirley. Visions of Reality (screenshot).

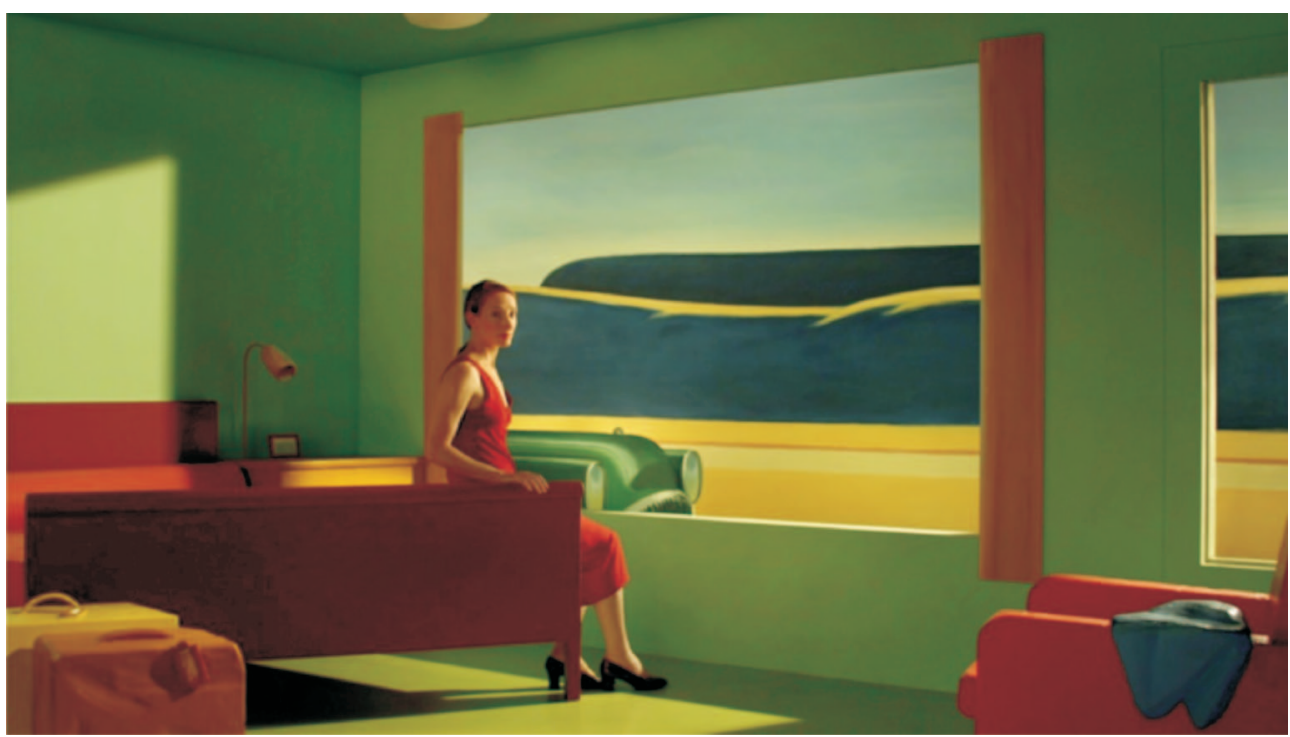

Figure 4. \#Musepose (screenshot).

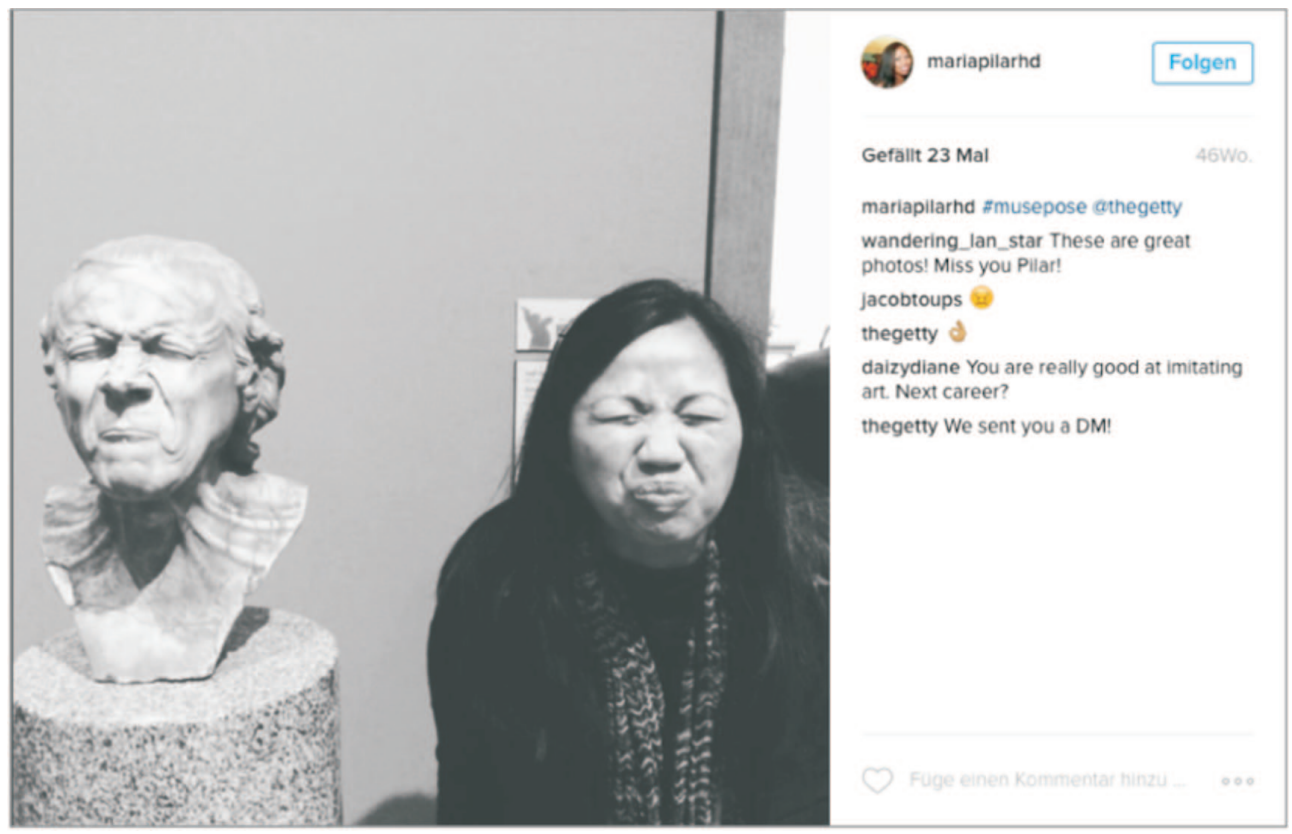


Figure 5. \#Musepose (screenshot).

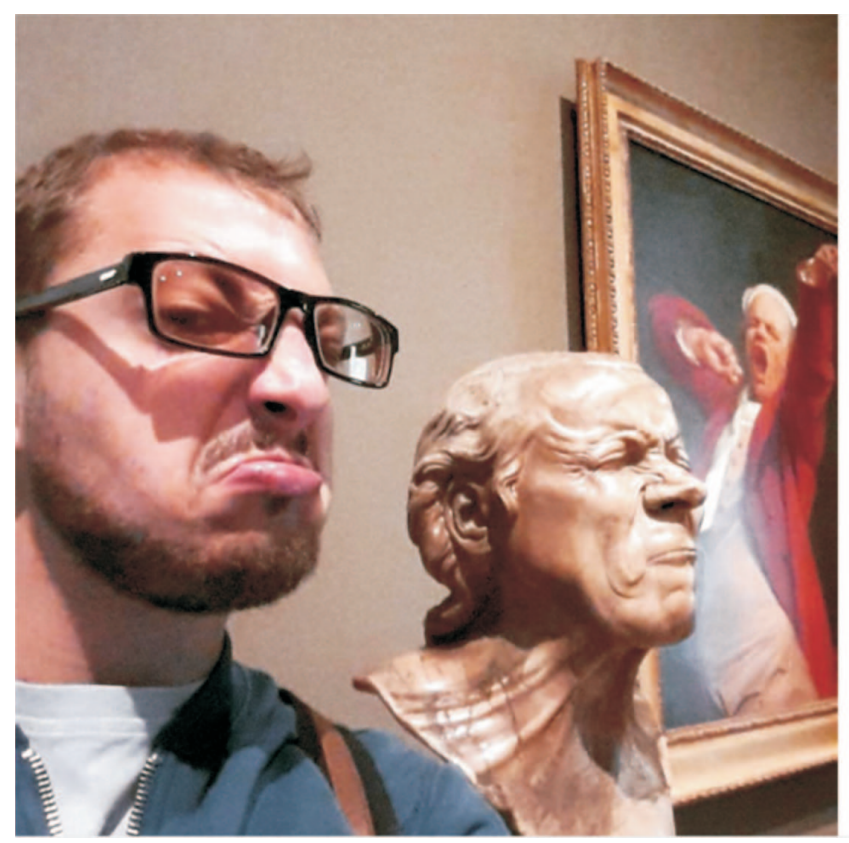

zackdemirtshyan - Folgen

Getty Museum

zackdemirtshyan \#losangeles

\#zackdemirtshyan \#vacation \#getty

\#gettymuseum \#musepose

gettyvilla Nice \#musepose

zackdemirtshyan @gettymuseum thanks Getty for wonderful exhibitions and great beer outside!!!

david_bramante $d$

zackdemirtshyan @breinvestment

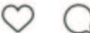

Gefällt $39 \mathrm{Mal}$

16. NOVEMBER 2016 